\title{
HUBUNGAN TINGKAT PENGETAHUAN PERAWAT TENTANG KESELAMATAN PASIEN DENGAN INSIDEN KESELAMATAN PASIEN DI RS AMINAH TAHUN 2021
}

\author{
Imaniar, Seriga Banjarnahor \\ Program Studi Ilmu Keperawatan, STIKes Murni Teguh \\ E-mail : imaniar.kep19@gmail.com; serigabanjarnahor@yahoo.com
}

\begin{abstract}
Knowledge is something related to the learning process. Patient safety is a system in which the hospital makes patient care safer. A Patient Safety Incident (IKP) is an event or situation that could potentially or result in injury to a patient that should not have occurred. This study aims to determine the relationship between the level of knowledge of nurses about patient safety with patient safety incidents at Aminah Hospital in 2021. This study is a descriptive quantitative correlation study with a cross sectional approach. The test carried out in this study is the chi square test. The population studied were nurses who were inpatient and outpatient at Aminah Hospital, samples taken were 55 people who were taken by means of probability sampling. The data were processed using univariate and bivariate analysis. From the chi square test results obtained $p$ value $=0.000(p<0.05)$. From the results of the research that has been done, it can be concluded that there is a relationship between nurses' knowledge of patient safety and patient safety incidents at Aminah Hospital. From the results of this study, it is expected that hospitals can improve the quality of nursing services, especially for health workers, especially nurses who act as nursing care providers. The quality of service is supported by the performance of nurses based on good knowledge.
\end{abstract}

Keywords: Knowledge, Patient Safety, Patient Safety Incident

\begin{abstract}
Abstrak
Pengetahuan merupakan sesuatu yang berkaitan dengan proses pembelajaran. Keselamatan pasien merupakan suatu sistem dimana rumah sakit membuat asuhan pasien lebih aman. Insiden Keselamatan Pasien (IKP) merupakan kejadian atau situasi yang dapat berpotensi atau mengakibatkan cedera pada pasien yang seharusnya tidak terjadi. Penelitian ini bertujuan untuk mengetahui hubungan tingkat pengetahuan perawat tentang keselamatan pasien dengan insiden keselamatan pasien di RS Aminah tahun 2021. Penelitian ini merupakan penelitian deskriptif korelasi metode kuantitatif dengan pendekatan penelitian cross sectional. Uji yang dilakukan pada penelitian ini adalah uji chi square. Populasi yang diteliti adalah perawat pelaksana di rawat inap dan rawat jalan RS Aminah, sampel yang diambil 55 orang yang diambil dengan cara probability sampling. Data diolah menggunakan analisa univariat dan bivariat. Dari hasil uji chi square di dapatkan $p$ value $=0,000(\mathrm{p}<0,05)$. Dari hasil penelitian yang telah dilakukan dapat disimpulkan bahwa adanya hubungan antara pengetahuan perawat tentang keselamatan pasien dengan insiden keselamatan pasien di RS Aminah. Diharapkan rumah sakit dapat meningkatkan kualitas pelayanan keperawatan terutama bagi tenaga kesehatan yang berperan sebagai pemberi asuhan keperawatan. Kualitas pelayanan didukung oleh kinerja perawat yang didasari oleh pengetahuan yang baik.
\end{abstract}

Kata kunci : Pengetahuan, Keselamatan Pasien, Insiden Keselamatan Pasien 


\section{PENDAHULUAN}

Rumah sakit di Indonesia perlu diregulasi tentang keselamatan pasien, pada peraturan Menteri Kesehatan (Permenkes) tentang keselamatan pasien di rumah sakit, mendukung upaya pelayanan kesehatan yang aman bagi pasien terdiri ada 6 (enam) sasaran keselamatan pasien (patient safety) [1]. Insiden yang paling umum terjadi pada prosedur bedah $(27 \%)$, kesalahan pengobatan $(18,3 \%)$ dan infeksi terkait perawatan kesehatan (12,2\%) [2]. Menurut Ministry Of Health Malaysia 2013 melaporkan angka insiden keselamatan pasien dalam rentang waktu Januari - Desember 2016 sebanyak 2.769 kejadian dan untuk negara Indonesia dalam rentang waktu 2006 - 2015 KKPRS melaporkan terdapat 877 kejadian keselamatan pasien [3]. Menurut Fatimah Data insiden keselamatan pasien melaporkan analisis penyebab terjadinya insiden $46 \%$ berkaitan dengan salah identifikasi, $36 \%$ dikarenakan karena komunikasi yang tidak efektif sehingga terjadi medication error, $18 \%$ dikarenakan prosedur tidak dijalankan [4].

Hubungan pengetahuan perawat tentang keselamatan pasien menunjukkan ada hubungan yang signifikan antara variabel pengetahuan perawat tentang keselamatan pasien dengan tingkat insiden [5]. Dalam penelitian sebelumnya juga membahas tentang hubungan pengetahuan perawat dengan penerapan standar JCI tentang keselamatan pasien menunjukkan ada hubungan yang signifikan antara variabel pengetahuan perawat dengan penerapan standart JCI tentang keselamatan pasien.

Rata - rata angka kejadian di RS Aminah tahun 2019 terjadi sejumlah 40 insiden, dimana dibagi menjadi 24 insiden $\mathrm{KNC}, 3$ insiden KPC, 6 insiden KTC dan 7 insiden KTD. Berdasarkan uraian tersebut maka peneliti tertarik untuk meneliti hubungan karakeristik perawat dalam penerapan sasaran keselamatan pasien di rumah sakit.

\section{METODE PENELITIAN}

Penelitian ini merupakan penelitian deskriptif korelasi metode kuantitatif dengan pendekatan penelitian cross sectional. Uji yang dilakukan pada penelitian ini adalah uji chic square. Populasi yang diteliti adalah perawat pelaksana di rawat inap dan rawat jalan RS Aminah, sampel didalam penelitian ini berjumlah 55 orang yang diambil dengan cara probability sampling. Data diolah menggunakan analisa univariat dan bivariat.

\section{HASIL PENELITIAN}

Analisa Univariat

Tabel 1. Karakteristik Responden

\begin{tabular}{cccc}
\hline No & Karakteristik & F & \% \\
\hline 1 & Jenis Kelamin & & \\
& Laki-laki & 12 & $21,8 \%$ \\
& Perempuan & 43 & $78,2 \%$ \\
\hline 2 & Umur & & \\
& $20-30$ & 46 & $83,6 \%$ \\
& $31-40$ & 7 & $12,7 \%$ \\
& $>40$ & 2 & $3,6 \%$ \\
\hline 3 & Pendidikan & 35 & $63,6 \%$ \\
& D3 & 1 & $1,8 \%$ \\
& SKep & 19 & $34,5 \%$ \\
& Ners & & \\
\hline 4 & Masa Kerja & 18 & $32,7 \%$ \\
& < 1 Tahun & 13 & $23,6 \%$ \\
& 1 - 2 Tahun & 24 & $43,6 \%$ \\
& $>2$ Tahun
\end{tabular}

Dari tabel di atas responden yang berjenis kelamin laki-laki 12 dengan presentase $21,8 \%$ dan perempuan 43 dengan presentase $78,2 \%$., responden berdasarkan umur di dapatkan responden dengan umur 20 - 30 tahun sebanyak 46 dengan presentase $83,6 \%, 31$ - 40 tahun sebanyak 7 dengan presentase $12,7 \%$ dan $>40$ tahun sebanyak 2 dengan presentase $3,6 \%$, responden berdasarkan pendidikan di dapatkan responden dengan pendidikan D3 sebanyak 35 dengan presentase $63,6 \%$, Skep sebanyak 1 dengan presentase $1,8 \%$, Ners sebanyak 19 dengan presentasi $34,5 \%$, dan responden berdasarkan masa kerja didapatkan responden dengan masa kerja $<1$ tahun 18 dengan presentase $32,7 \%$, masa kerja $1-2$ tahun sebanyak 13 dengan presentase $23,6 \%$, masa kerja > 2 tahun sebanyak 24 dengan presentase $43,6 \%$. 
Tabel 2. Pengetahuan Perawat Tentang Keselamatan Pasien Di RS Aminah Tahun 2021

\begin{tabular}{lcc}
\hline \multicolumn{1}{c}{ Pengetahuan } & F & \% \\
\hline Baik & 32 & $58,2 \%$ \\
\hline Cukup Baik & 23 & $41,8 \%$ \\
\hline \multicolumn{1}{c}{ Total } & 55 & $100 \%$ \\
\hline
\end{tabular}

Dari tabel diatas dapat diketahui bahwa pengetahuan perawat tentang keselamatan pasien adalah sebagian besar baik sebanyak 32 orang dengan presentasi $58,2 \%$ dan yang cukup baik sebanyak 23 orang dengan presentasi $41,8 \%$.

Tabel 3. Insiden Keselamatan Pasien Di RS Aminah Tahun 2021

\begin{tabular}{|c|c|c|}
\hline Insiden & $\mathbf{F}$ & $\%$ \\
\hline Rendah & 42 & $76,4 \%$ \\
\hline Tinggi & 13 & $23,6 \%$ \\
\hline Total & 55 & $100 \%$ \\
\hline
\end{tabular}

Dari tabel diatas dapat diketahui bahwa insiden keselamatan pasien adalah sebagian besar rendah sebanyak 42 dengan presentase $76,4 \%$ dan insiden tinggi sebanyak 13 dengan presentase $23,6 \%$.

\section{Analisa Brivariat}

Berdasarkan hasil uji chi square didapatkan hasil sebagai berikut:

Tabel 4. Hubungan Tingkat Pengetahuan Perawat Tentang Keselamatan Pasien Dengan Insiden Keselamatan Pasien Di RS Aminah Tahun 2021

\begin{tabular}{|c|c|c|c|c|}
\hline \multirow[t]{2}{*}{$\begin{array}{l}\text { Pengetahuan } \\
\text { perawat }\end{array}$} & \multicolumn{2}{|c|}{$\begin{array}{c}\text { Insiden } \\
\text { Keselamatan } \\
\text { Pasien }\end{array}$} & \multirow[t]{2}{*}{ Total } & \multirow{2}{*}{$\begin{array}{c}\text { P- } \\
\text { Valu } \\
\text { e }\end{array}$} \\
\hline & Rendah & Tinggi & & \\
\hline Baik & $58,2 \%$ & 0 & $58,2 \%$ & \multirow{3}{*}{0,000} \\
\hline Cukup Baik & $18,2 \%$ & $23,6 \%$ & $41,8 \%$ & \\
\hline Total & $76,4 \%$ & $23,6 \%$ & $100 \%$ & \\
\hline
\end{tabular}

Didapatkan responden yang memiliki pengetahuan tentang keselamatan pasien dengan kategori baik dan insiden rendah sebanyak 32 orang $(58,2 \%)$, sedangkan pengetahuan tentang keselamatan pasien dengan kategori baik dan insiden tinggi tidak ada $(0 \%)$. Sementara itu responden yang pengetahuannya cukup baik dan insiden rendah sebanyak 10 orang $(18,2 \%)$, sedangkan pengetahuan perawat cukup baik dan insiden tinggi sebanyak 13 orang $(23,6$ $\%)$.

Hasil analisa menggunakan uji chi square diperoleh nilai $p$ value 0,000 dimana hal ini bearti $p$ value $<0,05$ sehingga $\mathrm{Ha}$ diterima yang artinya adanya hubungan antara pengetahuan perawat tentang keselamatan pasien dengan insiden keselamatan pasien di RS Aminah tahun 2021.

\section{PEMBAHASAN}

Dari hasil penelitian didapat bahwa responden dengan jenis kelamin perempuan lebih banyak dari pada jenis kelamin laki-laki 12 orang dengan presentase $21,8 \%$ dan perempuan 43 orang dengan presentase 78,2 $\%$. Responden dengan rentan usia/umur 20 30 tahun terbanyak dengan persentase $83,6 \%$, dengan proposi umur $31-40$ tahun $12,7 \%$ dan $>40$ tahun $3,6 \%$. Tingkat pendidikan didapatkan bahwa responden dengan pendidikan D3 keperawatan sebanyak 63,6\%, Ners 34,5\%, Skep 1,8 \%. Dan masa kerja yang didapatkan dari responden $>2$ tahun terbanyak $43,6 \%,<1$ tahun $32,7 \%, 1-2$ tahun $23,6 \%$.

Berdasarkan hasil analisa hubungan pengetahuan dengan insiden keselamatan pasien didapat hasil bahwa pengetahuan tidak baik dan insiden rendah sebanyak 1 orang $(1,8 \%)$, sedangkan pengetahuan tentang keselamatan pasien tidak baik dan insiden tinggi sebanyak 13 orang $(23,6 \%)$. Sementara itu responden yang pengetahuannya baik dan insiden rendah sebanyak 41 orang $(74,5 \%)$, sedangkan pengetahuan perawat baik dan insiden tinggi tidak ada $(0,0 \%)$. Hasil uji chi square menunjukkan ada hubungan signifikan antara pengetahuan dengan insiden keselamatan pasien $(\mathrm{p}=0,000)$.

Pengetahuan perawat tentang keselamatan pasien jika ditelaah dari jawaban 
masing-masing aspek dari 6 sasaran keselamatan pasein dapat dijelaskan bahwa tentang pengurangan resiko infeksi terkait pelayanan kesehatan merupakan hal yang paling dipahami oleh perawat. Pemahaman yang baik tentang hal ini karena program cuci tangan pada perawat yang dilakukan di RS Aminah sudah cukup disosialisasikan dengan baik.

\section{KESIMPULAN}

Hasil penelitian yang telah dilakuikan di RS Aminah dapat diambil simpulan sebagai berikut :

1. Mayoritas tingkat pengetahuan perawat tentang keselamatan pasien berada pada kategori baik.

2. Mayoritas insiden keselamatan pasien berada pada katagori rendah

3. Ada hubungan antara pengetahuan perawat tentang keselamatan pasien dengan insiden keselamatan pasien di RS Aminah.

\section{SARAN}

Berdasarkan simpulan diatas maka peneliti dapat memberikan saran-saran sebagai berikut :

1. Bagi Instansi Rumah Sakit

Rumah sakit Aminah dapat meningkatkan kualitas pelayanan keperawatan terutama bagi perawat yang berperan sebagai pemberi asuhan keperawatan. Kualitas pelayanan didukung oleh kinerja perawat yang didasari oleh pengetahuan yang baik.

2. Bagi Instansi Pendidikan

Penelitian ini dapat dijadikan sebagai tambahan kepustakaan untuk mengembangkan ilmu pengetahuan dan kesehatan.

3. Bagi Peneliti selanjutnya

Hasil penelitian ini hanya menunjukkan domain pengetahuan perawat dalam pelaksanaan keselamatan pasien, maka diharapkan peneliti selanjutnya tidak hanya meneliti tentang pengetahuan dengan insiden keselamatan pasien tetapi juga pengaruh beban kerja dan kepatuhan perawat dalam keselamatan pasien serta dapat melakukan penelitian yang lebih baik

\section{REFERENSI}

1. Permenkes RI No. 11. (2017), Tentang Keselamatan Pasien. Jakarta : Depkes RI.

2. WHO. (2017). 10 Facts of Patient Safety. Dapat diakses dari: http://www.who.int/features/factfiles/patie nt_safety/patient_safety_fa cts/en/.

3. RSUDZA. (2017). Pentingnya Pelaporan Insiden Keselamtan Pasien Ruah Sakit. Rsudza.acehprov.go.id/tabloid/2017/12/29

4. Fatimah, F. S., Sulistiarini, L., \& Ata, U. A. (2018). Gambaran Pelaksanaan Identifikasi Pasien Sebelum Melakukan Tindakan Keperawatan di RSUD. 1(1), 2127.ISSN;2621-2668.

5. Novayanti, D. (2015). Pengaruh karakteristik, pengetahuan, dan keterampilan perawat terhadap pelaksanaan keselamatan pasien rawat inap di RSUP H. Adam Malik Medan. (Tesis). Universitas Sumatera Utara, Medan 